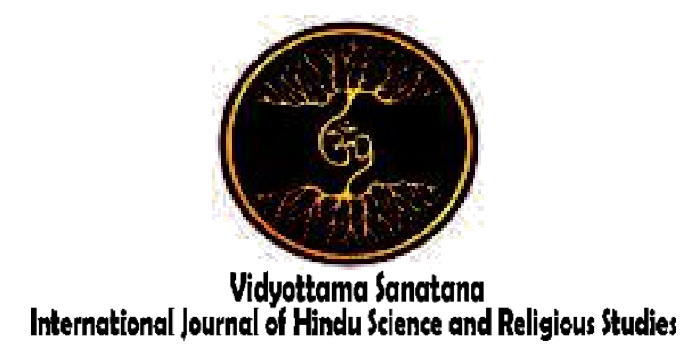

Vol. 3 No. 1 May 2019

\title{
THE CONCEPT OF HINDU COSMOLOGY IN THE TATTWA JNANA TEXT
}

\author{
By: \\ I Gusti Made Widya Sena \\ Institut Hindu Dharma Negeri Denpasar \\ E-mail : gusti_sena@yahoo.com
}

\begin{tabular}{|l|l|l|} 
Received: Desember 1, 2018 & Accepted: May 22, 2019 & Published: May 31, 2019 \\
\hline
\end{tabular}

\begin{abstract}
The truth in daily life is certainly a wholeness in implementing the tattwa, ethics and acara of Hinduism as tri basic framework of Hinduism in Bali. This is because until now the implementation of the teaching trilogy is still running and standing alone in an incomplete and comprehensive manner. Sometimes it is found in the field of implementation of acaras and ethics are not equipped with tattwa philosophy in it. So that the knowledge of the people will be more rooted and rely on the basic concept indeed. This of course will increasingly corner the minds of the people about the doctrine that is not fundamental.

One of the truths of tattwa written in the Vedic Scriptures is the concept of cosmology or the creation of the universe. Cosmology is one of the important knowledge in Hinduism, because cosmology not only provides knowledge about the creation of the universe, furthermore cosmology can explain the true nature of human beings, which so far is still very difficult to obtain. In Bali, this cosmological teaching is implied in local theology. Local theology that lived and developed in Bali until now is imbued with the teachings of the Vedic scriptures. Especially Siwaistic texts that always put forward the teachings of knowledge about the reality of God, the way to reach Him and the creation of the universe, both great bhuana agung and bhuana alit.
\end{abstract}

Keywords: Hindu Cosmology, Tattwa Jnana 


\section{Introduction}

Various ways to implement the teachings of Hinduism that are written in the Vedic Scriptures, be it the path of karma yoga (path of activity), bhakti yoga (path of devotion), jnana yoga (path of knowledge), and king yoga (path of meditation) must be studied so that someone has a complete understanding as an inseparable unity of links. This is done because the Vedas as the Hindu Scriptures are used by Hindus as a basis for guiding and guiding the lives of the people in carrying out all their daily activities. The comprehensive knowledge expressed in the Vedas makes the Vedas the source of truth in life. The truth in daily life is certainly wholeness in implementing tattwa teachings, ethics and Hinduism acara as tribasic frameworks of Hinduism in Bali. This is because until now the implementation of the above teaching trilogy still stands and runs on it is own intact and incomplete. Often in the field, we find the implementation of the acara and ethics are not equipped with tattwa philosophy in it. So that the knowledge of the Ummah will be rooted and relying on the basic concept is indeed that. This, of course, will further corner the people's thoughts on doctrines that are not strong and fundamental.

One of the truths of tattwa written in the Vedic Scriptures is the concept of cosmology or the creation of the universe. Cosmology is one of the important knowledge in Hinduism, because cosmology not only provides knowledge about the creation of the universe, cosmology can further explain the true nature of human beings, which so far are still very difficult to obtain. In Bali, the teachings of cosmology are implicit in local theology. Local theology that lived and developed in Bali until now was inspired by the teachings of the Vedic scriptures. Especially Shivaistic texts that always prioritize the teachings of the knowledge of the reality of God, the way to reach Him and the creation and fusion of the universe, both the bhuana agung and bhuana alit. For this reason, the knowledge and understanding and correct implementation of the concept of tattwa, especially regarding The Concept of Hindu Cosmology in the Tattwa Jnana Text is very important to be put forward in everyday life towards spiritual awareness and harmonious life.

\section{Result and Discussion 2.1 Hindu Cosmology}

Cosmology is derived from philosophy, as is the character or nature of philosophy which is the source of all science. Likewise, cosmology has links with various fields of science. Cosmology comes from the word "cosmology", which consists of two syllables, namely cosmos and logy. The word cosmos means the universe or universe, and the word logy means science. So Cosmology is the science of the universe (Donder, 2007: 1).

Another opinion states that cosmology is an investigation or theory of the origin and character, and the development of the universe as a regular system. Cosmology is a part of philosophy that believes in its description as a complete description of human philosophy with its structures and norms. The position of cosmology in a philosophical system is very close to ontology (general metaphysics), both looking for structures and fundamental norms for equality, only cosmology limits itself to the world of nature. While ontology tries to understand holistically between humans, the world and God.

Hindu cosmology is the knowledge of everything related to the universe. In the teachings of Hindu cosmology, the universe is built of five elements, namely: soil (solid), water (liquid), air (gas substance), fire (plasma), and ether. The five elements are called Panca Maha Bhuta or five material elements. Unlike general cosmology, Hindu cosmology places God first and foremost. As a forerunner or prime cause of this universe. In Hindu cosmology, the creation of this universe comes from God. From within the body or hiranya the universe was born, and then to Him, the universe was returned. Thus the universe and its contents according to Hindu cosmology experience repeated 
processes of birth, life, and death, as implied in the Bhagavad Gita IX, sloka 7 and 8 below:

Sarva bhütāni kaunteya prakṛtim yānti māmikam,

Kalpa ksaye punas tāni kalpādau visrjāmy aham

(Bhagavad Gita IX.7)

Translation:

All beings enter into my principle at the end of the circulation of Kalpa, O son of Kunti (Arjuna), and at the beginning of the next Kalpa I created them again ".

Prakṛtim svām avastabhya visrjāmi is extinct,

Bhūta grāmam imam krtsnamavasam prakrter vasat

(Bhagavad Gita IX.8)

Translation:

By moving My principles, I created many times all this being, powerless with the power of my wisdom.

The two verses above explain Hindu Cosmology. Creation of creatures, including the universe was created cyclic (circle) which repeatedly follows the shape of a circle that does not have its tip and base (anadi ananta) and places God as the beginning, middle and end of the existence of the cosmos.

\subsection{Tattwa Jnana Text}

In relation to this paper, the word Tattwa Jnana is the name of the text tattwa in Bali. The text is one of the texts belonging to the type of speech and the presentation is in the form of prose. In the Tattwa Jnana text, it is not clear who characterization or dialogue occurred between the teacher and the student, unlike other Shivaistic texts in Bali, where the advocacy and dialogue occur clearly. Between gods and humans, between gods and goddesses and so on. The Tattwa Jnana text which describes Shiva's secret teachings is structurally contained in the form of chapters or main sections. This text consists of eight chapters with a total number of sloka reaching 74 slokas. The chapter with the least number is in chapter VII, while the longest chapter is in chapter V. Each chapter (main part) in this text discusses certain topics. The topics are as:

1. The first chapter consists of 5 slokas which discuss cetana, acetana, Parama Siwa Tattwa, Sadasiwa Tattwa, and Atmika Tattwa. besides that in this chapter also mentioned what must be considered and studied by someone who wants to be free from the misery of incarnation. By learning and understanding Sang Hyang Tattwa Jnana well, then someone will be free from misery.

2. The second chapter consists of 5 slokas, a continuation of the first chapter that discusses the Bhatara Dharma developing its certain. Here it is mentioned about Citta, satwam, rajah, and Tamah. Pradhana tattwa is present in this chapter which produces pradhana-purusa.

3. The third chapter consists of 4 slokas also describes the origins and characteristics of Ahangkara who gave birth to Dasa Indriya, Panca Tan Matra and Panca Maha Bhuta. Ahangkara is divided into three parts, namely ahangkara the waikrta is buddi sattwa, ahangkara si taijasa is buddhi rajah and ahangkara the bhutadi is buddhi tamah.

4. This chapter consists of 7 slokas, discusses the understanding and distribution of loka sapta, patala sapta, the different roles with wages, and the understanding of satwam, rajah and tamah. Sapta loka consists of satya loka located at the top, then successively below it is maha loka, jana loka, tapa loka, swar loka, bhuwar loka, and bar loka. Sapta Patala consists of patala, 
vital, nitala, maha tala, sutala, tala-tala, and rasa tala.

5. The fifth chapter consists of 24 slokas, describing the Hyang Atma's punarbhawa, as well as its characteristics and characteristics. In this chapter, it is told how Atma got the fruit of karma during his life in the world and the implementation of the prayogasandhi teachings as medicine in escaping from the misery suffered by Atma.

6. Chapter VI consists of 11 verses discussing the embodiment of Sang Hyang Atma in the human body, atma gets influence from Panca Maha Bhuta, its relationship with Sad Rasa, Panca Tan Matra, sapta Bhuana, Sapta Parwata, Sapta Arnawa, Sapta Dwipa, and ten nadis. In this chapter, it is stated that Atma was born in the form of a human being, born to earth, lived and inhabited a physical body, infiltrated in sad rasa which is a sari-sari from Panca Maha Bhuta, namely land, water, light, wind, and air.

7. Chapter VII consists of 3 slokas discussing the notions of Wayu, Panca Atma, Dasa Indriya, the place of Sang Hyang Tri Purusa in the body, the place of Panca Rsi, Dewa Rsi, Sapta Rsi, Dewata and Widyadhara-widyadhari, Gandharwa-gandharwi. In this chapter also discusses how Sang Hyang Atma is divided into 5 parts, consisting of Atma, Paramatma, Antaratma, Suksmatma, and Niratma into a unity in the human mind. The eighth chapter consists of 15 slokas, discussing the notions of breath, tapa, yoga, and Samadhi. In this chapter, there is also a glimpse of the pradhana tattwa, ambek (mind) and prayogasandhi that cannot be carried out without samyagjnana guidance (true knowledge). That is why with the truth understanding and implementation in knowing prayogasandhi it is preferred to reach the world of liberation.

\subsection{The Concept of Cosmology}

In the Tattwa Jnana Text, The Tattwa Jnana text is Shivaistic Text that glorifies Lord Shiva as the highest form of God. The word Shiva in this text is the same as the word Brahman in Vedanta. To achieve deliverance and eliminate the misery of the incarnation one needs to learn the correct knowledge of Sang Hyang Tattwa Jnana. In Tattwa Jnana's text mentions:

Nihan kayatnākna de sang sewaka dharma, mahyun luputeng janma sangsāra, hana śanghyang tattwa jñ̄ana ngaranira, yatika kwruhakênanta rumuhun, lawanika dewatānya enak pwa wruh ta ring Sanghyang tattwa jūāna, niyata sira tumon janma sangsara mwang mantuka ri sangkaya. Aparan ika sinanggah Sanghyang tattwa jūāna ngaranira, sugyan mangkana linga sang para, anampih Sanghyang tattwa jñāna ngaranira, anung pinaka bungkah ning tattwa kabeh, ngya Iwirnya nihan

Translate:

This is what is worth noting by a servant of Dharma, who wants to be free from the misery of incarnation. There is a Tattwa Jñāna Sanghyang whose name you should know first, along with the dewatā. You will understand this misery of the incarnation and will return to its origin. What is called sanghyang tattwa jñāna? Perhaps this is the question of most people. There is only the Tattwa jñāna Sanghyang whose name is the basis of all tattwa. Which is that?

Repeated incarnation using the physical body of man causes continual 
misery. Knowledge of awareness and deliverance needs to be continuously studied and understood so that later on with the knowledge base spiritual awareness will be obtained. Cosmology comes from the word cosmology which consists of two words, namely from the word cosmos and logy, the word cosmos means the universe or universe, and the word logy means science. So cosmology is the science of the universe. Cosmology is the science that studies the ins and outs of the universe. The term cosmology in Hinduism can be equated with the term Virat vidya because the virat means the cosmos or the universe, and vidya is the meaning of knowledge (Donder, 2007: 77).

The universe is also called the virat, also called the great bhuana or universe. Bhuana comes from Sanskrit bhuana (bhu) which means earth, material or object; and the great word comes from the Old Javanese language, which is from the word (gang, gong, and ageng) which means big. Thus the word bhuana means large earth or universe. Whereas the word universe comes from a combination of Arabic and Sanskrit, the word nature comes from Arabic, which means all of the existing creations and the word universe are from Sanskrta, namely samastha, which means whole.

Jagat (jagad) highway comes from Sanskrit, namely from the word universe which means objects, matter, the world, while the word great means big. So the universe is the world, matter, objects that have all of God's creation in this universe, in other words, the universe is the universe and all of His creations. Being a great bhuana, the universe and the universe mean all of God's creation. The concept of creation (cosmology) in the Tattwa Jnana Text begins with two main universal elements. The two main elements are cetana and acetana. As described in the following Tattwa Jnana text: Creation occurs because of the union of cetana and acetana, cetana is an element of consciousness, an element of knowledge called Siwa Tattwa, while acetana is an unconscious, forgotten and confused element called Maya Tattwa. The existence of Shiva
Tattwa and Maya Tattwa is described as follows.

Cetana acetana, cetana ngaranya jñāna wruh mangêt, ring tutur tan pablik lupa, acetana ngaranya ikang lupa wyamoha tan kahanan tutur. Ikang cetana lawan acetana, yeka sinanggah śinanggah siwatattwa lawan māyātattwa, ikang cetana yeka śiwatattwa ikang acetana yeka māyātattw, padha litnya mwang sūksmanya, kunang kasor nikang māyātattwa, kewala lupa tan kahanan tutur, ta ya pinakāwaknya, awang-awang uwung-uwung, tan pagamongan, lipa wiparita, swabhawa nikang māyātattwa. Tutur prakāśa pwa swabhwa nikang siwatattwa, ikang sinangguh siwatattwa, tiga prabhedanya lwirnya, paramaśiwatattwa, sadāśiwatattwa, àtmikatattwa.

Translate:

Cetana, Acetàna. Cetana is: jñāna, that is: knowing, remember, remembering consciousness that does not change into forgetfulness. Acetana is: forgetting, confused not having consciousness. That figure is called Siwatattwa. Cetana is Siwatattwa and acetana is māyātattwa. Both small and halūs. Māyātattwa is lower than Siwatattwa. Māyātattwa does not have traits, does not have jñāna, only forgets not having consciousness. Absence as a body, free blank no one hinders. Forgot to remember anything, so are the properties of Mātātattwa. Atiwatattwa has conscious, clear, radiant qualities. The so-called Siwatattwa are of three kinds, namely: Paramaśiwatattwa, Sadāśiwatattwa, amtamikatattwa.

Maya Tattwa is different from Shiva Tattwa because Maya Tattwa has no consciousness, is empty and forgets. The virtual element tattwa is a worldly element or what is called the element pradhana, while 
the element of Shiva Tattwa is an element of consciousness commonly referred to as the element purusa in the text of Bhuana Kosa. Shiva tattva consists of three parts, namely: Paramaśiwatattwa, Sadāśiwatattwa, and amtamikatattwa. The Paramaśiwatattwa is Bhațāra in a formless, immovable, unsteady, non-moving, non-flowing, non-originating, none-purpose, non-starting, not ending, only still motionless without motion. Silent and eternal. All of this universe is fulfilled, covered, fully infiltrated, supported, no space filled, filled with the universe by it. Cannot be reduced, cannot be added. Without works, also without purpose. Can not be disturbed by good or bad deeds. It can't be known as a whole. And he doesn't know the past, the future, and the present. It is not hindered by time, always no day is missing to $\mathrm{Him}$. He is eternal. Thus the properties of Bhatāa in niṣkala are symbols of Bhațāra Paramaśiwatattwa. In line with the concept above. The concept of Shiva in Lontar Wrhaspati Tattwa is also referred to as Paramasiwa because it is transcendent, described as having no character, because it is immeasurable, indistinguishable, incomparable, uncontaminated, invisible, omnipresent, eternal, permanent, not diminished, and without end. $\mathrm{He}$ is not characterized because he does not have characteristics. He cannot be compared, because there is no other like him, $\mathrm{He}$ is not tainted, because $\mathrm{He}$ is not tainted. He does not appear because $\mathrm{He}$ cannot be seen. He is because $\mathrm{He}$ is in all things. $\mathrm{He}$ is immortal because $\mathrm{He}$ is formless, He remains because $\mathrm{He}$ does not move, He does not diminish because He remains intact.

Shiva is inconceivable (aprameya), is an infinite nature. He cannot be given a limit (anidesya), because $\mathrm{He}$ does not have the characteristics. He cannot be compared (his salary), because $\mathrm{He}$ has no equal to Him. He is not sick (anamaya), because $\mathrm{He}$ is holy. He is called suksma, because he cannot be seen. $\mathrm{He}$ Sarwagata because $\mathrm{He}$ is in everything, he fulfills the universe. He remains calm, becau because have an origin. It is sturdy (dhruwa), because it does not move, remains stable. He never decreases (awyaya), because $\mathrm{He}$ is always intact. The text which also explains that God is called Bhatara Siwa is in the text of Bhuana Kosa. $\mathrm{He}$ is Almighty, formless, colorless, unthinkable, unmixed, immovable, unlimited and so on. This is in accordance with the explanation of Bhuana Kosa, I. 19, as:

Tan karekĕtan mala, tan palwir, tan pagātra, wyāpaka, yonggwan Sang Hyang Așta Śiwa, tan pacala, wiśeșa ya.

Translate:

Without stain, without form, without form, but mastering / fulfilling nature. It was Sang Hyang Asta Siwa's dwelling place, the main place without reproach.

In line with Lontar Bhuana Kosa, in the Tattwa Jnana Text it also descri,bes the existence of Sang Hyang Siwa in the body, as in the table below: The second concept of Shiva Tattwa is Sadāśiwatattwa. Sadāśiwatattwa is wyāpāra. This means that he is fulfilled by sarwajña (all-knowing) and sarwakāryakartā (all work). Sarwajña sarwakāryakarthā is padmāsana as the seat of bhatārā Siwa, called Cadhuśakti. Cadhuśakti consists of four types, namely: Jñānaśakti, Wibhūśakti, Prabhuśakti and Kryaśakti.

The Jñānaśakti is divided into three types, namely: dūrādarsana, dūrāśrawana, dūrātmaka. Dūrādarsana is seeing far and near. Dūrāśrawana is hearing sounds far and near. Dūrätmaka is knowing the deeds that are far and near. Wibhūakti is no shortage in the whole universe. Prabhuśakti is impenetrable from everything $\mathrm{He}$ wants. Kriyaśakti is holding the whole universe, especially the dewatā all, such as Brahma, Wișnu, İ́swara, pañcaṛ̦i, Saptaṛsi, Dewarși, Indra, Yama Waruṇa, Kubera, Weśrawana, Widyādhara, Gandharwa, Dānawa, Daitya, Rākșasa, Bhutayakșa, Bhūtakala , Bhūtapiśāca, so too is this realm, prthiwī (land), āpah (water), teja (light), wāyu (air), ākâśa (ether), moon, sun planet, that is all the works of Bhatāāā Sadāśiwatattwa in the realm: straāstra Sanghyang, Amagama, spell science (waidya), logic (tarka), grammar 
(wyākaraṇa), arithmetic (ganita). Bhatāa Sadāśiwatattwa is called Bhațāra Ādipramāṇa his name, besides also referred to as Bhațāra Jagatnātha, Bhațāra kāraṇa, Bhațāra Parameśwara, Bhațāra teacher, Bhațāra Mahulun, Bhațāra Waśawaśitwa. the attributes of Bhațāra Sadāśiwatattwa include: He created, but He himself was not created. He has the power to carry out and move. No one can defeat His power. He has power over all this world. He who has the realm of noses and niskala.

The third concept is mtmikatattwa. Bhațārā Sadāśiwatattwa with the characteristics of ūtaprota. Uta is as a fire in a log, fire in bamboo wood is invisible. This is the case with Bhatāāā Sadāśiwatattwa who infiltrated māyātattwa. Not visible and not caught. He expanded to meet māyātattwa. Prota is like a spanish gem, clear clear glittering, bright not covered in anything. Then he is attached to the war, so the color of the gem changes, covered by the wara which is attached to the māyattattwa. It does not seem he can be known anymore to fulfill the māyātattwa. Because it is covered by war melekata attached to the gem. For that the way is to separat,e the jewel with that color.

That's when the gem returns to its clear color. The attached color will acaraually return to its original form. Likewise, Bhațārā Sadāśiwatattwa, who infiltrated gives awareness to the māyātattwa. The nature of mātattwa is dirty (mala). Sadāśiwatattwa is decorated and adhered to by dirty (mala). The chetan is attached to the mala, decorated and covered by māyātattwa. Acaraually the cetana became ina,ctive, no longer sarwājña, no longer sarwakāryakartā, in the end it really seemed that his consciousness was very small. Then he is called Ātmikatattwa, Sanghyang mtmawiśeșa, Bhațārā, Dharma which fills the universe. It is the soul of the universe, all beings. Such is the equation as the sun. One is active in itself, but the light spreads in the direction of all places, fulfilling the universe that shines on good and bad, which smells bad and which smells good. Only the cetanany spreads to fill the universe. Turning into a bigger one, it became true for all beings. Māyā is what is considered to be cynical which gives awareness. After that Bhațārā Siwa developed his cetan.

Bhațārā Siwa wants to see real things. So from that he gave Sanghyang mtmā which he met with the Tattwa Pradhāna. The Tattwa Pradhāna is the son of Māyātattwa. That is why the nature of Pradhānatattwa is the same as the virtual tattwa, forgetting without consciousness and not remembering anything. This is the same as the human condition called sleep. The nature of Pradhānatattwa is forgetting, while the nature of Sanghyang Ātmā is always remembered. With a convergent meeting it is called the meeting of pradhāna-purușa. When the meeting of pradhāna with purușa gave birth to Citta and Guna. Citta is the gross form of purușa, while the use is the result. That is why pradhānatattwa are given awareness by puruṣa so as to produce use. The Guna consists of three types, namely, Sattwa, Rajah, Tamah. That is what is called Triguna which is used as guna (quality) by Citta. As implied in the following Tattwa Jnana sloka text 7-9:

Citta ngaranya cetana sang purușa karaktan kopaêngga tri guna, citta ngaranya wkasan lakșașanya meaningful. Yan sattwa prakāśa rumakêt irikang citta, yeka prād widagdha, wêruh ring yogya opponent yogya, akamūlyan deyamawāmbek, ahadyan tngên, tan guragada, tan babakujar, bhakti tonandugaduga, asih ta ya ring kasyasih, anumeda ring hinadina, tuning sungsut, satya bhakti, arumapting, the thing, somanya discourse, atên ta ya ngucap straāstra, kamuni wacananya utsāhāngusing guṇa pangwaruh kasamyagjñānan, tan pamali nghêla, tan kneng sungsut kewala bungah patinghalanya, as mangdadyakên arșa ring the mangrêngö mahardhika oahambêkanya mangdadyakên trpti paritușta ring, citta ning para, masor 
ta ya ringabhiprāya, manggā kociwaho, tan kêpommahār sukhāmbêk ning para, tatanahangkāra, tan moha denyāmawa prawêrti, flowering śāntā lilang, atning nirāwārana tan patalutuh, atah pinaka jñānanya, aśrī patinghalanya, yeka wyakti nikang citta sattwa, nahan lakșananikang citta sāwa ,anikang citta sattwa, an rumakêt sattwa, an rumakêt irikang citta.

(Tattwa Jnana, 7)

Translate:

Citta is the image of the Purusa who is decorated with Triguna. then his name is Citta. Remember the characteristics. If Sattwa is brightly illuminated, he will become a wise person who knows what is called proper and what is called inappropriate, both the way he behaves, even though he is powerful, he is not rude, does not say as long as said, be respectful, look straight ; he put affection on those who suffer, comforted those who despised those who were sad, loyal and devoted (arumpating alanya?), gentle words, truly he carried out the teachings of the straāstra and what he said. Trying to pursue good character, kasamyagjñānan knowledge. There is no fatigue, no sadness, just stop happily. Any of his movements make people happy to see him. His words make happy hear. The noble heart causes calm and joy in the hearts of the people. Not greedy and willing to budge (mango kociwaha tan keponumahār sukambeking para?). unselfish, not misguided by his behavior, but delighted and just plain (clean) light that becomes his heart, sweet in his face. That is the essence of the citta sattwa, which is attached to the citta.

Nihan lakșana ning citta tamah, an rumakêt irikang citta, abêyêt, almêh, guhya, Simpanêh, kalusa, amangana, tananghel, atīs, arip bot turu, göng mūạha, göng rāga, göng elik, göng hyun, göng wiṣy, dread ta ya lasuklasonita , mapulang mature against the children of rabinya, mangkana wyakti nikang citta tamah, an rumakêt irikang citta.

Translate:

These are the signs of the citta tamah, when they cling to the mind. Heavy, reluctant, secret, pedestal, dirty, not satisfied to eat. Cold, haunting, strong sleep, very dumb, big lust. Very jealous, wanting hard, very passionate, hooked with copulation. Capur sleeps with his wife and child. Thus the essence of cittaamah and so are the signs, if it clings to the mind.

Sattwa, rajah and tamah are attached to the mind (citta) that causes âtmā to manifest repeatedly. Likewise if only the sattwa fills in the mind that causes àtmā to achieve deliverance (kamokșan). If sattwa meets the tattoo, the bright-luminous citta. That is what causes ātmā to come to heaven, because God wants to do good, then it is the rajah who carries out all the wishes of Sattwa. Thus the essence of the truth of the tattoo participates in heaven, carried by sattwa. If sattwa meets rajah tamah, the light shines on that citta and that causes the ātmā to become human, because sattwa, rajah and tamah of his will are not in line.

The characteristics of sattwa are doing good, carrying out dharma, giving, doing service. The characteristics of tattoo are hard and angry, while the characteristics of tamah are hidden, reluctant to eat and sleep. Thus, sattwa, rajah and tamah should not be in line but contradictory. That is why there is no good or bad behavior that occurs only by one of them. Thus actually manifests as a human being that is Sanghyang mtmā. Thus the triguña is inherent in the mind. Triguna's meeting with Citta, Buddhi was born. Buddha's nature is buddhi without idep (mind), because buddhi itself is a dream (mind). Buddhi is like not knowing but he 
knows. Buddhi is like without fuss but it is cetana. Buddhi only remembers good and bad. So Buddhi is the crude form of Triguna, who is given awareness by the citta.

From Buddhi was born Ahangkara. Ahangkara this is the crude form of citta. That is what cetana gives awareness. This is because cetana is getting bigger and bigger. Citta gives awareness to Ahangkar. That is infiltrated by the power-giving kriyā śakti Bhatarā. Kriyāśakti Bhatarā pramāṇa as his life ahangkarā, as his Buddhist life. That is why pramāna is another name ahangkarā. Because claiming to determine who exists or does not exist, claims to carry out good deeds and bad deeds. And also the quality (quality) is confessing everything he has. The characteristics of Ahangkara are: "Mine, my breath, I say, my mind, my body. There are three types of ahangkara, namely: ahangkara the waikṛta is buddhist sattwa, ahangkara si taijasa is buddhi rajah, ahangkara the bhūtādi is buddhi tamah. That is the type of Ahangkara. The functions of each ahangkara are as stated in the following Tattwa Jnana sloka text 12-13:

The yeki wuwusên, ahangkāra si wekrêra, yeka magawe manah, mwang daśendriya, lwirnya, cakșu, otarota, ghrāna, jihwā, twak, nahan tang sinangguh paendendriya ngaranya, wāk, pāni, pāda, upastha, pāyu sinangguh pañcakarmendriya ngaranya, papinda nikang pañcendriya kasawlas manah, nahan gave liking the wekrêta ahangkara.

(Tatwa Jnana, 12)

Translate:

Let us tell you the function of each Ahangkāra the waikṛta is to cause the existence of the manah, and the 10 senses, namely: cakșu (eye), otarota (ear), ghrāna (nose), jihwā (tongue), tweak (skin), so-called pañcandriya. Wāk (mouth), pāṇi (hand), pāda (foot), pasta (male sex), pāyu (plan), so it is called pañcandriya called Daśendriya. The elacarah name is manah. Such is the function of Ahangkara the Waikta.
Kunang ikang ahangkara si bhütādi, yekāgawe pañcatanmātra, lwirnya, śabdatanmātra, sparśatanmātra, rūpatanmātra, gandhatanmātra, śabdatanmātra, rasatanmātra, gandhatanmātra. ŚSabdatanmātra ngaranya, cover talingāta kalih, hana śabda karêngö, lit nikang śabda, yea śabdatanmātra the meaning. Śparśatanmātra ngaranya, hana wāyu madrês, west prahāra kunang, marên pwekang wāyu, lit nikang sumilirūmêsêping kulit, yeka sparśatanmātra, meaning. Rūpatanmātra ngaranya, duwêgi kalasandya, amatup sanghyang additya kulwan, hana ta tejanira kawkas mātramātra, lit nikang teja, yea rüpatanmātra the meaning. Rasatanmātra said, the cadre was amangên șadrasa, the class was offered, hana ta sesse the mātra kawkas ring tongue, lit nikang rasa, they felt tanmatra ngara. The Gandhatanmātra is the name, the kadyangganing the fragrance, the candanāgaru firefly, lungha tang wāsa, rika, hana ta ya śe na nikang gandha ring irung, yes, continuous connection, ling nikang gandha, yeka gandhatanmātra.

(Tatwa Jnana, 13)

Translate:

The ahangkāra the bhūtādi is what causes the existence of pañcatanmātra, namely: śabdatanmātra, sparśatanmātra, rūpatanmātra, gandhatanmātra, śabdatanmātra, rasatanmātra, gandhatanmātra, called: Śabdatanmātra is: close your ears, there is a voice. The softness of the voice, śabdatanmātra its name. Sparśatanmātra is: there are heavy winds and hurricanes, After stopping the wind. The smooth flowing that seeps into the skin is the name sparśatanmātra. Rūpatanmātra is: at dusk, the sun sets in the west. There is a light that is dimly lit. The 
smoothness of the light is is given to be met with Pradhana Tattwa. rūpatanmātra. The name This meeting of remembering and forgetting Rasatanmātra is: just like eating is what later in the process of creation is șadrasa (taste six). After eating, there called the meeting of purusa and pradhana. is still a feeling of scarring on the When meeting purusa and pradhana this was tongue. The smooth taste is the name born the citta which is a symbol of the gross rasatanmātra. Gandhatanmātra is: as form of purusa. Then after the citta, Guna is well as the fragrant smell of born, as a symbol of pradhana tattwa which sandalwood and Majagau. All the fragrant objects are gone. There is a waste of the smell on the nose, that's what the kiss smells. The smell is gandhatanmātra.

From pañca tanmāntra, pañcamahābhūta is born. Ākāśa was born from śabdatanmātra. Like an empty sky, nothing hinders anything, sabda as the use (quality). Wāyu (wind) was born from sparśatanmātra. Sparśa as use (quality). Teja was born from rūpa tanmātra. Shining brightly. Heat as its nature. Rūpa as guṇa. Āpah was born from rasa tanmātra. Absorbs wetness. Dadrasa as guna. Pṛthiwī was born from the gandhatanmātra. Space that is rough. Gandha as guna. Gandha has three types, namely: surabhi, asurabhi and gandhasadharanah. Surabhi is a fragrant smell: Asurabhi is a foul odor and gandhasadharanah is a smell that is not fragrant nor is it rotten. Such is the nature of the prthiwi $\overline{1}$. That is the essence of crude elements. Pṛthiwī, āpah, teja, wāyu, ākāsa is what is made bhuwana by bhatāāā. The move up the higher the situation and the levels. The more above Tattwa is made guna by the tattwa below. From the description above, the process of creating the universe according to the Tattwa Jnana Text occurs through nine stages. these stages are due to Bhațārā Siwa developing his certain. Bhatāāā Siwa wants to see tangible objects, so that is what he gave Sanghyang Ātmā from Purusa Tattwa which he met with the Tattwa Pradhāna.

Starting from Lord Siwa gave rise to Cetana and Acetana as elements of consciousness and unconsciousness, as elements of Shiva Tattwa and Maya Tattwa. then God wants to see objects created by Him become real, so that Sang Hyang Atma is given consciousness by purusa.

From pañca tanmāntra, pañcamahābhūta is born. Śkāśa was born from śabdatanmātra. Like an empty sky, nothing hinders anything, daabda as the use (quality). Wāyu (wind) was born from sparśatanmātra. Sparśa as use (quality). Teja was born from rūpatanmātra. Shining brightly. Heat as its nature. Rūpa as gunanya. Āpah was born from rasatanmātra. Absorbs wetness. Dadirasa as gunanya. Pṛthiwī was born from the gandhatanmātra. Space that is rough. Gandha as gunanya. Gandha has three types, namely: surabhi, asurabhi and gandhasadharanah. Surabhi is a fragrant smell: Asurabhi is a foul odor and gandhasadharanah is a smell that is not fragrant nor is it rotten. Such is the nature of the prthiwi. That is the essence of crude elements. Pṛthiwī, āpah, teja, wāyu, ākāsa is what is made bhuwana by bhațāā. The move up the higher the situation and the levels. The more above Tattwa is made guna by the tattwa below. From the description above, the process of creating the universe according to the Tattwa Jnana Text occurs through nine stages. these stages are due to Bhațārā Siwa developing his certain. Bhațārā Siwa wants to see tangible objects, so that is what he gave Sanghyang Ātmā from Purusa Tattwa which he met with the Tattwa Pradhāna.

From Siwa gave rise to Cetana and Acetana as elements of consciousness and unconsciousness, as elements of Shiva Tattwa and Maya Tattwa. then God wants to see objects created by Him become real, so that Sang Hyang Atma is given to be met with Pradhana Tattwa. This meeting of remembering and forgetting is what later in the process of creation is called the meeting of purusa and pradhana. When meeting 
purusa and pradhana this was born the citta which is a symbol of the gross form of purusa. Then after the citta, Guna is born, as a symbol of pradhana tattwa which is given consciousness by purusa (Wiguna, 2018).

Then from the meeting of Tri Guna with the Citta buddhi was born. Buddhi in this text is a symbol of the (mind). As a rough form of Tri Guna who was given awareness by the citta. From Buddha was born Ahangkara. Ahangkara is a sense of recognition. Confess that everything is his property, be it material, the breath released from the nose, the words issued from the mouth, my mind to my body. Ahangkara is the cause of the emergence of Panca Tanmatra, namely the word tanmatra (seed of sound), sparsa tanmatra (seed of touch), the likeness of tanmatra (seed of sight), the taste of tanmatra (seed of taste) and gandha tanmatra (seed of smell). From Panca Tanmatra, Panca Maha Bhuta was born. Akasa was born from the words of tanmatra, bayu born from sparsa tanmatra, but was born from the form of tanmatra, apah born from the taste of tanmatra and pertiwi born from gandha tanmatra. The creation theory in the Tattwa Jnana Text is a cycle. The emergence of the universe was born from its most subtle nature and then manifested into traits which gradually became more coarse until acaraually macrocosm and microcosm formed.

\section{Conclusion}

The concept of creation (cosmology) in the Tattwa Jnana Text begins with Bhatara Siwa giving rise to Cetana and Acetana as elements of consciousness and unconsciousness, as elements of Shiva Tattwa and Maya Tattwa. then God wants to see objects created by Him become real, so that Sang Hyang Atma is given to be met with Pradhana Tattwa. This meeting of remembering and forgetting is what later in the process of creation is called the meeting of purusa and pradhana. When meeting purusa and pradhana this was born the citta which is a symbol of the gross form of purusa. Then after the citta, Guna is born, as a symbol of pradhana tattwa which is given consciousness by purusa.

Then from the meeting of Tri Guna with the Citta buddhi was born. Buddhi in this text is a symbol of the (mind). As a rough form of Tri Guna who was given awareness by the citta. From Buddha was born Ahangkara. Ahangkara is the cause of the emergence of Panca Tanmatra, namely the word tanmatra (seed of sound), sparsa tanmatra (seed of touch), lifelikeness of tanmatra (seed of sight), taste of tanmatra (seed of taste) and gandha tanmatra (seed of smell). From Panca Tanmatra, Panca Maha Bhuta was born. Akasa was born from the words of tanmatra, bayu born from sparsa tanmatra, but was born from the form of tanmatra, apah born from the taste of tanmatra and pertiwi born from gandha tanmatra. The theory of the creation of the universe in Tattwa Jnana's text is a cycle. The emergence of the universe was born from its most subtle nature and then manifested into traits which gradually became more coarse until acaraually macrocosm and microcosm formed.

\section{References}

Donder, I Ketut. 2007. Virat Vidya: Kosmologi Hindu. Surabaya: Paramita.

Pudja, G. 1999. Bhagavad Gita (Pancama Weda). Surabaya: Paramita.

Sena, I Gusti Made Widya. 2016. Konsep Kosmologi Hindu Dalam Teks Bhuana Kosa. IHDN Denpasar.

Tim Penyusun.1998. Tattwa Jnana. Surabaya: Paramita.

Wiguna, I. M. A. (2018). The Perception Of Hindus In Denpasar City To The Abolition Of Sin In The Text Of Siva Puraana. Vidyottama Sanatana: International Journal of Hindu Science and Religious Studies, 2(1), 119-131. 